\title{
New Sources and Old
}

\section{Narratives}

\section{Roundtable on Soviet Famines}

\author{
J. A R C H G E T T Y
}

My research has been about repression within the Soviet Communist Party, so the Ukrainian famine has been on the periphery of my interests. I therefore come to it as a bit of an outsider. But some aspects of the debate are dismayingly familiar. These include wild accusations of defending Stalin and an interpretive consensus that is resistant to the anomalies of new evidence and, sometimes, of logic.

It has long been a tenet of the Ukrainian diaspora that the Russians and then the Soviets have waged a war against Ukrainians for centuries. Yet many scholars not connected to Ukrainian centres or interests had for a long time rejected the idea of a deliberate Soviet policy of genocide by starvation. Moshe Lewin, one of the leading experts on peasants and agriculture, pithily dismissed the idea as 'crap'. Holodomor (to kill by starvation), a term coined in the I970s by the Ukrainian diaspora, has come into wide currency. Were it not for a new Ukrainian state with a resurgent nationalism in search of a useable past, the claims of a Ukrainian genocide intentionally perpetrated by Stalin might not be quite so pressing today. There is a new Ukrainian Institute of National Memory to sanitise wartime collaboration and focus national enmity on Russia, and scholars who have rejected the idea of intentional Holodomor risk accusations of being 'Holodomor-deniers' or worse.

For example, Alexander Etkind makes the astonishing claim that when I noted the absence of documents proving Stalin's intention to deliberately starve Ukraine, I was saying that 'we cannot blame him for this catastrophe'. Of course we can. Whether from ignorance or ideology, Stalin was author and prosecutor of collectivisation policies that resulted in millions of deaths. That has never been disputed by me or anyone else. But obviously bad policy is not the same as the intentional genocide of a nation.

There is little doubt that the famine that devastated Ukraine and other regions was to some extent man-made, but whether or not it was intentional remains controversial. Was it the result of genuine grain shortages (as Wheatcroft has shown), of Stalin's misunderstanding of the peasant village (as Lewin has shown), his insatiable demands for grain, his reluctance to back down, his ideological 
obtuseness or a deliberate attempt to instrumentalise hunger to destroy Ukrainian nationalism?

In the past few years several categories of archival documents have become available that can shed light on such questions. These include a limited number of secret police files (primarily on the Gulag camp system), parts of Stalin's personal archive and the 'special folders' of the Politburo.

Unfortunately, we still do not have a single document directly stating Stalin's motivations and intentions aside from his demands for grain. Yet the new documents do tell us some things circumstantially. They show that behind the scenes the Stalinists spoke to each other with the same vocabulary and conceptual framework they used in public propaganda. They said many of the same things to each other that they said to the party rank and file and, to some extent, to the public. And they were also not shy about writing things down, as when they shot innocent hostages, killed most of their own Central Committee or murdered 20,000 Polish officers in the Katyn forest. But as far as I know, in writing or speaking to each other privately they never mentioned hunger as a weapon or as anything other than a disaster or, perversely, a conspiracy against the regime.

Several classes of newly released documents, including Stalin's personal archive and correspondence, strongly suggest that he really believed that food difficulties in the late I920s, resistance to collectivisation, peasant flight from starving regions and even the famine itself were caused by organised kulak resistance or the cowardice and timidity of his agents on the ground. For him, this was not only scapegoating to defend a stupid policy, although there was plenty of that too. He seems to have really believed it. The insidious machinations of enemy kulaks forever haunted the Stalinist imagination. Even in the I970s Molotov fended off questions about the innocence of arrested people by suggesting that maybe they really had been covert and conniving kulaks.

The question of a purported Stalin genocide, as it has been posed, must be a question of intention. I am thus mystified by Graziosi's belief that it is 'misguided' to ask whether the famine resulted from mismanagement or from a conscious genocidal plan. Isn't that in fact the main question here? I understand the debate to be about whether or not this was purposeful genocide, and the question of intent would appear to be at the center of that question.

The new sources sometimes raise as many questions as they answer about this main element of a criminal investigation: motive. Our attempt to get at Stalin's purpose must rely on making inferences from the actual events we know and the documents we have. The prosecutorial case for intentional genocide must be especially circumstantial, as we do not have documents proving the case and a number of documents that do not fit it.

Among the new sources, the special folders (osobye papki) of the Politburo have not been fully explored. These are ultra-secret files into which the Stalinists put papers even more sensitive than the usually top-secret Politburo agendas and decisions. They were Politburo eyes-only files designed to be hidden not only from foreign countries and the Soviet population and, as I have written elsewhere, from other 
parts of their own bureaucracy. One hand must not know what the other is doing.

The special folders are difficult to work with, which explains why they have not been fully mined. This mass of Politburo documents is arranged chronologically, is un-indexed and has only general uninformative inventories. The folders have mixed contents: orders on preparing the I936 show trial of Zinoviev and Kamenev are found adjacent to a document on wheat subsidies. Guidelines for distributing weather reports are followed on the next page by an order to arrest already detained Polish officers in preparation for shooting them. Because of this chaos, scholars searching for ultra-secret decisions on a particular topic are obliged to tediously page through hundreds of thick files in hopes of finding something relevant. Not every scholar including me - has had enough time to do so completely. But, as Fitzpatrick suggests, relying on someone else's published collection of documents (whose principles of selection are often unclear, if not suspicious) is not the same thing as systematic archival research.

Looking at what these new sources suggest, it seems that some things do not fit the Holodomor narrative regarding Stalin's intentions. In the special folders we find, for example, secret Stalin orders during the famine to reduce grain exports, to reduce grain exactions or to return seed grain to villages. Presumably Stalin judged these things to be ultra-secret so as not to disturb his party face: there must be no let up. To hesitate could spark a widespread retreat. If some provinces found out that he was helping others, the image of an implacable policy would be weakened. We can suspect from some recent research that such palliative measures were too little too late but even so they would appear to be counterproductive to an intentional genocide.

We know that one of the reasons Stalin launched dekulakisation and then collectivisation had to do with the grain crisis at the end of the I920s. If the Bolsheviks' main social support, the urban workers, went hungry the regime could fall. If the army went hungry, the country could fall. One suspects that Stalin was juggling feeding peasants, feeding the army, feeding the workers and feeding foreign exports to pay for industrialisation. Until we fully exploit all the special folder orders we cannot know his calculus exactly. Have we seen all of these documents?

The special folders also shed light on another concern, a military one. At the beginning of the I930s the Politburo spent more than a usual amount of time secretly studying and worrying about having enough soldiers for the Red Army. The draft age at the time was twenty-one (soon to be reduced to eighteen), so Soviet men eligible for the draft in I935 would have been born in I9I4, the first year of the First World War. During that war, I2 million men were mobilised to fight and of course were not making sons. And although our demographic data for the war and the I9I 8-2I Civil War are incomplete, it stands to reason that the loss of some 8 million people to war, civil war, disease and starvation (especially in Ukraine) not only further damaged the birth rate but also hit infants and children especially hard. Starting in I930 the Politburo was worried about the demographic results of this I9I4-2I catastrophe. They were eager to know how many young men would be available for military service in various years in the I930s, and they repeatedly demanded detailed reports 
on the matter. Given this concern, it is not clear why Stalin would want to starve to death so many prospective soldiers at this precise time. Deliberately starving Ukraine does not easily fit the concern for maintaining the army.

Stalin was also concerned about a Polish threat to Ukraine. He famously told his lieutenant Lazar Kaganovich that if they weren't careful, 'we could lose Ukraine'. Behind this perhaps alarmist sentiment, though, there was a valid concern. For centuries invaders had come through the flat plain, and most recently Poles and Germans had done so in the Civil War. As it turned out, they would come this way again in 194I. This long flat border was hard to seal, and the I93os would see several unsuccessful police attempts to close this relatively porous frontier. At one point Stalin charged his up and coming security expert Nikolai Ezhov to take charge of the effort.

As usual, Stalin overreacted to a perceived threat. He was worried about manoeuvres of Polish intelligence to weaken Soviet power in Ukraine. Old Polish organisations ('Pilsudskyists' and the 'Polish Military Organisation' among others) remained in his thinking as real threats, and he repeatedly directed the political police to investigate any signs of Polish political machinations in Ukraine. Poles were deported from border regions, purged from factories and executed in large numbers in the mass 'national operations' of I937-8. Given what he imagined to be an enemy threat just across the border, deliberately starving Ukraine in order to destroy the social and economic fabric along a wide open border does not easily fit Stalin's well-documented concern about security on that frontier.

New documents also call into question the Ukrainian article of faith that Stalin sought to destroy Ukrainian nationalism with an intentional famine. Stalin, as the party's expert on nationality policy, understood the danger nationalism posed to the communist vision and he killed or imprisoned huge numbers of separatist politicians of many nationalities both inside and outside the party. We don't know how many Ukrainian nationalists were executed in comparison with those from other republics, but, statistically speaking, many other nationalities were more at risk to be inmates of the Gulag than were Ukrainians. Secret police Gulag documents show that Ukrainians were statistically under-represented in the Gulag in proportion to their population. Belorussians, Uzbeks, Georgians, Armenians, Poles, Jews and especially Russians were statistically more likely to find themselves Gulag prisoners than Ukrainians were.

Many scholars argue that nationalism is 'imagined' by an intelligentsia and adopted by politically active groups who then speak for the nation, usually without asking it. In the constituent parts of the Soviet Union, notably including Ukraine, nationalism was the project of an intelligentsia that was born in the nineteenth century, that became active in the Russian Revolution and that was eventually perceived by the Bolsheviks as separatist and ruthlessly crushed.

But it is by no means clear that peasants, in Ukraine or elsewhere, tended to be nationalists in great numbers. Peasants traditionally identify themselves more in terms of locality, language and religion than citizenship or national affiliation, the categories we intellectuals naturally understand. If, as many argue, nationalism is an imagined 
community based on the Enlightenment, the printing press and industrialisation, it is difficult to imagine Ukrainian peasants (and those in starving Kazakhstan, North Caucasus and Volga regions) imagining it, or Stalin thinking that they did and feeling threatened by them on that score. In my view it makes sense to separate policies that persecuted nationalist intellectuals from those that resulted in starving peasants in Ukraine and elsewhere. War against the peasantry and its way of life is not the same thing as war against 'bourgeois nationalism', the term used by the Stalinists that is revealing here.

Here Graziosi falls into a reductionist fallacy which, as one of my teachers said long ago, means saying 'all this is nothing but that'. For him, 'any analysis should start from the interpenetration' of the social and the national, the connection between the two being 'evident'. Start? Such an interpenetration, if it exists, should more properly be part of a conclusion rather than an 'evident' a priori starting point. Actually, as neither starting point nor conclusion do we confuse the two in other fields of history because in many historical situations, and in real life, it is evident that class and nationalism cut across each other in many ways.

Graziosi's unexamined and historically unique association of these two different categories serves no purpose except to bolster the contention that Stalin intended to exterminate Ukrainians or Ukrainian nationalism. As Etkind notes, we have documents from Stalin that speak of destroying class enemies. But Stalin's rhetoric about destroying (not, mind you, killing) class enemies does not mean he was speaking of killing nations. Only via a facile conflation of class and nation can we assert that Stalin meant to kill nations.

Many of the new Soviet documents do not fit an intentional genocide narrative. Until we fully exploit all the new materials, such a conclusion seems premature, unpersuasive and polemical, notwithstanding the confidence with which its partisans have asserted a vague and circumstantial case, often in support of a Ukrainian national project.

I am surprised that my colleagues continue to drag poor Lemkin into the matter. He was writing some seventy-five years ago without access to a fraction of the documentation we have today. Faced with a mass of documents on Stalinist repression, surely we can do better than to worry about his observations, or the United Nations or Nuremberg definitions for that matter. Their definitions were important in their day, but to try to jam a mass of new evidence we have barely started to exploit into their categories appears to me to be a strange and fruitless exercise. The world and its savage history have become more complicated since then; there is tragically a greater number and variety of mass deaths in many places.

I agree with many of my colleagues here that more comparative work needs to be done comparing the famine in Ukraine with those elsewhere in the Soviet Union. Beyond that, more efforts could be made to put the Ukrainian famine into broader comparative frameworks with famines outside the Soviet Union. How have other authoritarian and democratic regimes coped with them? What choices have they made about distribution of scarce food? What part does sealing off affected regions and stopping hungry migrations to the towns play in famine 
management or mismanagement? To what extent were such measures nefarious or pragmatic?

For example, what are we to make of Britain's handling of the Bengal famine of 1943 in which upwards of 4 million Bengalis starved to death? As Bengalis starved, Britain continued to export grain from India and forbade grain imports from Australia, diverting them instead to British soldiers and to Mediterranean storage in preparation for British military actions in the Balkans. Can we judge Winston Churchill, the author of these policies, as an author of intentional genocide, insofar as he blamed Indians for their own starvation because they bred 'like rabbits?' One wonders how he squared his imperial racism with his view of genocide as 'a crime without a name'. 